\title{
Effects of Supplementation Diet Containing Microcystis aeruginosa on Haematological and Biochemical Changes in Labeo rohita Infected with Aeromonas hydrophila
}

Jyotirmayee Pradhan ${ }^{1}$ and Basanta Kumar Das ${ }^{2 *}$

${ }^{1}$ Government College (Autonomous), Angul-759143, Odisha, India

${ }^{2}$ Central Institute of Freshwater Aquaculture (CIFA), Kausalyaganga, Bhubaneswar-751 002, Odisha, India

\begin{abstract}
An experiment of 100 days duration was conducted to test the effect of Microcystis aeruginosa in Labeo rohita against Aeromonas hydrophila. The rohu fingerlings $(22 \pm 2 \mathrm{~g})$ were fed with the experimental diets incorporated with different concentrations of $M$. aeruginosa @ $0 \mathrm{~g} \mathrm{~kg}^{-1}, 0.5 \mathrm{~g} \mathrm{~kg}^{-1}, 1 \mathrm{~g} \mathrm{~kg}^{-1}$ and $5 \mathrm{~g} \mathrm{~kg}^{-1}$. Replicate groups of fish were fed for three month daily @4\% body weight. At an interval of 30 days blood and serum samples were assayed for different haematological [total erythrocyte count (TEC), total leucocyte count (TLC), haemoglobin] and biochemical [blood glucose, serum aspartate aminotransferase (AST), serum alanine aminotransferase (ALT) and alkaline phosphatase (ALP)] parameters. Significantly $(p \leq 0.05)$ increased haemoglobin content and TLC was observed in Microcystis treated group. It was observed that the serum AST activity was significantly $(p \leq 0.05)$ decreased to all the treated groups of fish as compared to control on entire assay period. Serum ALT activity was significantly $(\mathrm{p} \leq 0.05)$ different to all the treated groups of fish on day 60 , on day 90 and on day 10 (except group B) bacterial post challenge as compared to control. After 90 days, fish were challenged with $A$. hydrophila and mortality (\%) was recorded up to day 10 post challenge. Highest percentage of survival $(72 \%)$ was noticed in the group fed

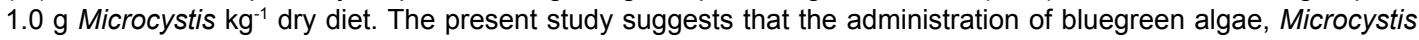
aeruginosa supplementation diets for 100 days protects the hematological and biochemical parameters in $L$. rohita from A. hydrophila.
\end{abstract}

Keywords: Aeromonas hydrophila; ALP; AST; Haemoglobin; Microcystis aeruginosa; Labeo rohita

\section{Introduction}

Nutrient supplementation in fish diets has been an economically promising method for improving the performance of different intensive fish production systems. To enhance a more economically sustainable aquaculture in the current millennium, many feed ingredient alternatives to fish meal at varying levels are now being sought. Thus functional feed additives strategy has recently gained considerable attention. From nutritional point of view, it does not only provide the essential nutrients required for normal physiological functioning, but also serve as a medium by which fish receive other components that may positively affect their health [1]. Several sectors of the aquaculture industry would benefit if cultured organisms were conferred with enhanced feed efficiency, growth performance, and disease resistance without environmental conflicts [2]. The other methods of preventing disease include immunostimulation through alteration of the diet and feeding practices [3]. In aquaculture, there are many studies reporting a variety of substances including bacterial [4], algal [5], animal and plant products [6-9] can be used as immunostimulants to enhance non-specific immune system of cultured fish species. With a detailed understanding of the efficacy and limitations of immunostimulants, they may become powerful tools to control fish diseases.

Microcystis aeruginosa (Kützing) is a unicellular, colonial bluegreen alga (family Chroococcaceae [10]. Ingestion of waters containing high concentrations of Microcystis can cause abdominal stress in humans leading to precautionary beach closures and can kill dogs and farm animals if they drink significant quantities of the bloom waters. However, due to their adverse effects on higher organisms, several cyanobacterial metabolites are regarded as health-threatening toxins and have caused serious concern among water authorities worldwide. But Microcystis has been recognized in recent years as a producer of a high number of secondary metabolites. Microcystis aeruginosa shows antibacterial and anti viral activity against the Gram-positive bacterium Staphylococcus aureus, some selected Gram-negative fish pathogens and influenza A virus [11-14]. It has been also reported that Microcystis stimulates the immunity and makes L. rohita more resistant to infection by A. hydrophila when fed in dried form in feed [15].

Fish should be fed with a balanced diet as nutritional deficiency can have an adverse impact on disease resistance. The analysis of blood indices has proven to be a valuable approach for analyzing the health status of farmed animals as these indices provide reliable information on metabolic disorders, deficiencies and chronic stress status before they are present in a clinical setting [16]. Haematological study is of immense importance when diagnostically evaluating fish health as in human health [17]. Enzymes are biochemical macromolecules that control metabolic processes of organisms, thus a slight variation in enzyme activities would affect the organism [18]. Thus, by estimating the enzyme activities in an organism, we can easily identify disturbances in its metabolism. In this study we monitored the disturbance of metabolism in fingerlings of $L$. rohita by feeding them

*Corresponding author: Das BK, Fish Health Management Division, Central Institute of Freshwater Aquaculture (CIFA),P. O. Kausalyaganga, Bhubaneswar-751 002, Odisha, India, Tel: 0674-2465446-228; E-mail: basantadas@yahoo.com

Received December 18, 2014; Accepted January 13, 2015; Published February 15, 2015

Citation: Pradhan J, Das BK (2015) Effects of Supplementation Diet Containing Microcystis Aeruginosa on Haematological and Biochemical Changes in Labeo Rohita Infected with Aeromonas Hydrophila. J Aquac Res Development 6: 315. doi:10.4172/2155-9546.1000315

Copyright: ( $) 2015$ Pradhan J, et al. This is an open-access article distributed under the terms of the Creative Commons Attribution License, which permits unrestricted use, distribution, and reproduction in any medium, provided the original author and source are credited. 
to Microcystis diet. This study was designed to evaluate the effect of feeding of Microcystis in the raw forms at different dietary levels on some haematological and biochemical profile of infected fish in $L$. rohita against $A$. hydrophila.

\section{Material and Methods}

\section{Microcystis aeruginosa}

Microcystis bloom was collected from Bindusagar, Bhubaneswar, India, with the help of plankton net made of bolting silk cloth (mesh size, $20 \mu)$. Collected samples were washed three times in MilliQ (Millipore, USA) water to remove suspended particles adhered to it and finally filtered (Whatman Filter paper Size 40). Harvested Microcystis (514 g wet weight) was dried under room temperature for 2-3 days and the dry weight of the algae was $110 \mathrm{~g}$. Then it was powdered. For each experiment, the required quantity of Microcystis powder was included in the feed.

\section{Pathogen}

Aeromonas hydrophila (ATCC 49140) was cultured in nutrient broth (Himedia) for $24 \mathrm{~h}$ at $37^{\circ} \mathrm{C}$. The culture broth was centrifuged at $3000 \mathrm{xg}$ for $10 \mathrm{~min}$. The supernatant was discarded and the pellet was resuspended in phosphate buffered saline (PBS, pH 7.4), and the OD of the solution was adjusted to 1.5 at $456 \mathrm{~nm}$, which corresponded to $1 \times 10^{7}$ cells $\mathrm{ml}^{-1}$. These bacterial suspensions were serially diluted using standard dilution technique with PBS and used for the challenge experiment.

\section{Preparation of fish feed}

The proximate composition of the basal diet was $39.4 \%$ crude protein, $7.4 \%$ lipids, $14.6 \%$ ash, $7.1 \%$ moisture and $3 \%$ fibre as per the

\begin{tabular}{|l|c|}
\hline Ingredients & Quantity included (g kg-1 diet) \\
\hline Groundnut oil cake & 400 \\
\hline Fish meal & 250 \\
\hline Rice bran & 200 \\
\hline Soya bean meal & 120 \\
\hline Vitamins and minerals mixture & 20 \\
\hline Starch & 10 \\
\hline Composition & Quantity $\mathbf{~ k g}^{-1}$ ) vitamin-mineral mixture \\
\hline Vitamin A & $2000000 \mathrm{IU}$ \\
\hline Vitamin D3 & $400000 \mathrm{IU}$ \\
\hline Vitamin B2 & $0.8 \mathrm{~g}$ \\
\hline Vitamin E & $300 \mathrm{IU}$ \\
\hline Vitamin K & $0.4 \mathrm{~g}$ \\
\hline Calcium pathtothernate & $1 \mathrm{~g}$ \\
\hline Nicotinamide & $40 \mathrm{~g}$ \\
\hline Vitamin B12 & $2.4 \mathrm{~g}$ \\
\hline Choline chloride & $60 \mathrm{~g}$ \\
\hline Calcium & $300 \mathrm{~g}$ \\
\hline Mangenese & $11 \mathrm{~g}$ \\
\hline lodine & $0.4 \mathrm{~g}$ \\
\hline Iron & $3.0 \mathrm{~g}$ \\
\hline Zinc & $6.0 \mathrm{~g}$ \\
\hline Copper & $0.8 \mathrm{~g}$ \\
\hline Cobalt & $0.18 \mathrm{~g}$ \\
\hline Calculat & \\
\hline
\end{tabular}

Calculated crude protein: $40 \%$; estimated crude protein: $39.6 \%$; calculated lipid content: $5 \%$; estimated lipid content: $7.2 \%$.

Supplies the above vitamin-mineral premix (Suplevite M) used in feed formulation per kg of feed were procured from Sarabhai Chemicals, Wadi, Baroda, India.

Table 1: Percentage inclusion of ingredients in basal diet with desired crude protein and lipid level [19]. method described by Misra et al. [19] (Table 1). Three experimental diets were formulated by including the required proportions of different feed ingredients such as ground nut oil cake, rice bran, fish meal, soyabean meal, vitamin \& mineral mixture [7]. Powdered forms of $M$. aeruginosa were added to the above formulation at the rate of $0.1 \mathrm{~g}, 0.5 \mathrm{~g}$ and $1.0 \mathrm{~g} \mathrm{Kg}^{-1}$ feed. Dry ingredients were mixed thoroughly and $1 \%$ binder was added. Water was added and mixed thoroughly in a mixer for $20 \mathrm{~min}$. The resulting dough was pelleted, dried at room temperature for $48 \mathrm{~h}$ and then stored in airtight containers until fed.

\section{Experimental design}

For experiment, total 240 numbers of acclimatized rohu fingerlings were taken and divided into four groups (A, B, C and D) with feeding of Microcystis at the rate of $0,0.5,1.0$ and $5.0 \mathrm{~g} \mathrm{~kg}^{-1}$ feed for 90 days. Duplicate tanks containing 30 numbers of fish were maintained for each group. After 90 days of feeding trail, 15 fish of duplicate tanks of each group were challenged intraperitonially with bacterial pathogen, A. hydrophila at the rate of $1 \times 10^{5} \mathrm{CFU}$ per fish. Blood and serum samples were collected from each group and examined for the following parameter, such as total erythrocyte count, total leucocyte count, haemoglobin, glucose, serum aspartate amino transferase, serum alanine amino transferase and alkaline phosphatase.

\section{Sampling}

Feed was suspended from fish for $24 \mathrm{~h}$ before blood samples were collected. From randomly picked fish $(\mathrm{n}=20$ from each subgroup) at 30 -day intervals, after anaesthetizing with $0.1 \mathrm{ppm}$ MS-222. Blood was collected from the caudal vein with a 1-mL plastic syringe ringed with heparin and stored at $4^{\circ} \mathrm{C}$ and used the same day. Blood samples were also collected without heparin, allowed to clot, centrifuged at $7000 \mathrm{~g}$ and sera collected and refrigerated. From each group twelve and eight fishes were sampled for serum and blood, respectively, and kept in a separate tank. Sera and blood were pooled into six groups, depending upon volume, for estimation of immunological and biochemical parameters [15].

\section{Determination of haematological parameters}

The collected blood samples were immediately subjected to haematological analysis. The haemoglobin content of different blood samples collected was measured by cyanomethemoglobin method as per Van Kampen and Zijlstra [20]. Reagent solution (5 ml) containing potassium hexacyanoferrate (III) solution (potassium hexacyanoferrate III $0.6 \mathrm{mmol} / \mathrm{l}$, potassium phosphate buffer 0.5 $\mathrm{mmol} / \mathrm{l} ; \mathrm{pH}$ 7.2), potassium cyanide solution (potassium cyanide $0.75 \mathrm{mmol} / \mathrm{lit}$, potassium phosphate buffer $2.5 \mathrm{mmol} / \mathrm{l}$; $\mathrm{pH} 7.2$ and detergent $0.1 \mathrm{~g} / \mathrm{l}$ ) was taken in a cleaned and dry test tube and then $0.002 \mathrm{ml}$ of blood was added to it. Simultaneously a blank reading was taken. It was mixed thoroughly and incubated at $20-25^{\circ} \mathrm{C}$. Absorbance was taken at an optical density $546 \mathrm{~nm}$ using the Bio-Rad Spectrophotometer. The haemoglobin was expressed as $\mathrm{g} \%$. The blood was diluted with appropriated diluting fluids for total erythrocyte count and total leucocyte counts were determined using improved Neubauer haemocytometer and calculated [21]. Replicated counts were made for each blood samples. The TEC and TLC count was expressed as cells per $\mathrm{mm}^{3}$.

\section{Determination of blood/serum biochemical Parameters}

The different sera samples collected earlier were analysed for AST and ALT following the procedure of Wallnofer et al. [22] using diagnostic kits (Bayer Diagnostics, Baroda, India). Serum ALP was 
Citation: Pradhan J, Das BK (2015) Effects of Supplementation Diet Containing Microcystis Aeruginosa on Haematological and Biochemical Changes in Labeo Rohita Infected with Aeromonas Hydrophila. J Aquac Res Development 6: 315. doi:10.4172/2155-9546.1000315

Page 3 of 5

determined by the procedure of Rosalki et al. [23]. Blood glucose content was estimated following the procedure of Schmidt [24] using standard kits (as per the manufacture's instructions; Roche diagnostic).

\section{Challenge of fish}

After 90 days of feeding, 15 fish from each subgroup was challenged intraperitoneally with a lethal dose of $A$. hydrophila $\left(1 \times 10^{5} \mathrm{CFU}\right.$ per fish) and observed for a 10-day period for mortality. Cumulative mortality percentage was determined over 10 days. Haematological and biochemical parameters were assayed in post challenged groups of survived fish as per the methods described earlier.

\section{Statistical analysis}

All experiments were performed in duplicate. All statistical analyses were performed by the Statistical Analysis System (SAS) program package. Data were expressed as mean \pm standard error (S.E). The data were analyzed by the one-way analysis of variance (ANOVA) and mean differences among experimental groups were evaluated using Duncan's multiple range tests (DMRT) at the $\mathrm{p} \leq 0.05$ significance level [25].

\section{Results}

\section{Haematological indices}

Significantly $(\mathrm{p} \leq 0.05)$ different haemoglobin content was observed in group of fish fed with $5 \mathrm{~g} \mathrm{~kg}^{-1}$ Microcystis (D) on day 60, B on day 90 and $\mathrm{C}$ on day 10 bacterial post challenge period. However, the group of fish fed with Microcystis powder showed insignificant $(\mathrm{p}>0.05)$ difference haemoglobin level as compared to control on day 30 day of exposure period.

Insignificant difference ( $\mathrm{p}>0.05)$ of TLC was found in Microcystis fed fish on day 30 of exposure period. The entire treatment group showed significantly ( $\mathrm{p} \leq 0.05)$ different TLC as compared to control on day 90 and on day 100 (i.e. day 10 post challenge) exposure period. Similarly the significant $(\mathrm{p} \leq 0.05)$ difference was observed in B and D as compared to control on day 60 of observation period.

The group of fish fed with Microcystis showed significantly increased ( $\mathrm{p} \leq 0.05$ ) TEC in $\mathrm{C}$ on day 90 and on day 10 post challenge period as compared to their respective control. An insignificant ( $p>0.05)$ difference TEC was found in the entire treatment groups as compared to control on day 30 and on day 60 day of exposure period (Table 2).

\section{Serum/blood biochemical indices}

The group of fish fed with Microcystis was found a significantly $(\mathrm{p} \leq 0.05)$ decrease of blood glucose level in the treatment groups as compared to control at all the day of exposure period (except B on day 60 and day 90). There is no significant change of blood glucose level was observed in the entire experimental group in comparison to control on day 90 (Figure 1).

The level of AST was significantly ( $\mathrm{p} \leq 0.05$ ) different to all the treated groups of fish on day 60 (except group D), day 90 and after bacterial post challenge as compared to control. But no significant difference was found within treatment groups (except B) on day 30 of observation period (Figure 2).

The group of fish fed with Microcystis showed a significantly ( $\mathrm{p} \leq$ 0.05) different in ALT activity on day 60, day 90 and on day 10 post challenge (except group of fish fed $0.5 \mathrm{~g} \mathrm{~kg}^{-1}$ ) as compared to their respective control. But there was no significant difference was noticed between treated groups and control on day 30 of exposure period

\begin{tabular}{|c|c|c|c|c|c|}
\hline \multirow[b]{2}{*}{ Parameters } & \multirow[b]{2}{*}{ Groups } & \multicolumn{3}{|c|}{ Pre challenge } & \multirow{2}{*}{\begin{tabular}{|c|} 
Post challenge \\
100 days
\end{tabular}} \\
\hline & & 30 days & 60 days & 90 days & \\
\hline \multirow[t]{4}{*}{$\mathrm{HB}(\mathrm{g} \%)$} & A & $8.20 \pm 0.63^{a}$ & $7.00 \pm 0.69^{b}$ & $7.55 \pm 0.95^{b}$ & $8.01 \pm 0.22^{b}$ \\
\hline & B & $7.65 \pm 0.32^{\mathrm{a}}$ & $8.24 \pm 0.46^{\mathrm{ab}}$ & $10.25 \pm 0.3^{a}$ & $7.45 \pm 0.60^{b}$ \\
\hline & C & $9.22 \pm 0.46^{\mathrm{a}}$ & $8.35 \pm 0.52^{\mathrm{ab}}$ & $9.22 \pm 0.41^{\mathrm{ab}}$ & $9.99 \pm 0.38^{a}$ \\
\hline & D & $8.02 \pm 0.62^{\mathrm{a}}$ & $9.65 \pm 0.27^{\mathrm{a}}$ & $8.002 \pm 0.3^{b}$ & $8.25 \pm 0.42^{b}$ \\
\hline \multirow[t]{4}{*}{ TLC } & A & $14.02 \pm 0.60^{a}$ & $13.22 \pm 0.57^{c}$ & $14.57 \pm 0.56^{b}$ & $15.96 \pm 0.55^{c}$ \\
\hline & B & $13.98 \pm 1.07^{a}$ & $19.25 \pm 0.59^{a}$ & $20.00 \pm 0.67^{a}$ & $19.22 \pm 0.40^{b}$ \\
\hline & C & $15.21 \pm 0.47^{a}$ & $15.02 \pm 0.41^{b c}$ & $19.11 \pm 1.00^{a}$ & $18.19 \pm 0.73^{b}$ \\
\hline & $\mathrm{D}$ & $14.52 \pm 0.72^{a}$ & $16.66 \pm 0.72^{b}$ & $20.21 \pm 0.39^{a}$ & $22.33 \pm 0.69^{a}$ \\
\hline \multirow[t]{4}{*}{ TEC } & A & $0.71 \pm 0.12^{\mathrm{a}}$ & $0.81 \pm 0.05^{\mathrm{a}}$ & $0.73 \pm 0.08^{b}$ & $0.94 \pm 0.09^{b}$ \\
\hline & B & $0.82 \pm 0.05^{\mathrm{a}}$ & $0.92 \pm 0.06^{a}$ & $0.82 \pm 0.04^{b}$ & $0.90 \pm 0.03^{b}$ \\
\hline & C & $0.73 \pm 0.04^{\mathrm{a}}$ & $0.99 \pm 0.08^{a}$ & $1.22 \pm 0.15^{\mathrm{a}}$ & $1.50 \pm 0.05^{\mathrm{a}}$ \\
\hline & D & $0.78 \pm 0.09^{a}$ & $1.23 \pm 0.21^{a}$ & $0.87 \pm 0.08^{b}$ & $0.92 \pm 0.19^{b}$ \\
\hline
\end{tabular}

Note: Data are expressed as mean \pm S.E. Superscript column wise on right hand side for particular treatment group are significantly $(P<0.05)$ different from the control group. MaC-Control group, Ma1-0.5 gkg-1, Ma2-1.0 gkg-1 and Ma3-5.0 gkg-1 Microcystis aeruginosa fed group.

Table 2: Effect of oral feeding of Microcystis powder on haematological parameters of $L$. rohita followed by i. p. challenge of $A$. hydrophila after 90 days.

$$
\mathrm{A}(0 \mathrm{~g} \mathrm{~kg}-1)=\mathrm{B}(0.5 \mathrm{~g} \mathrm{~kg}-1)
$$

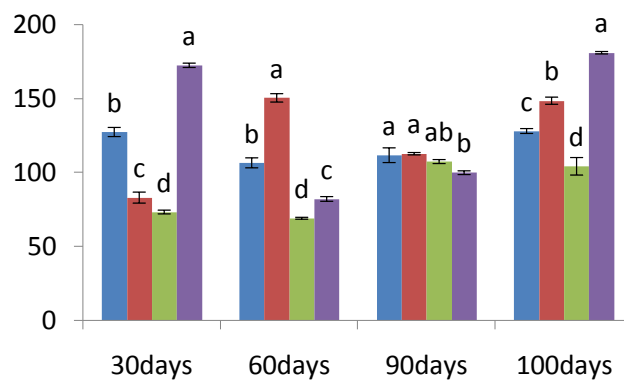

Figure 1: Effect of Microcystis on blood glucose level ( $\mathrm{g} \%$ ) of Labeo rohita on different assay days during the experimental period. Bars bearing common superscripts are not significant at $5 \%$ level in comparison to each other $(n=6)$.

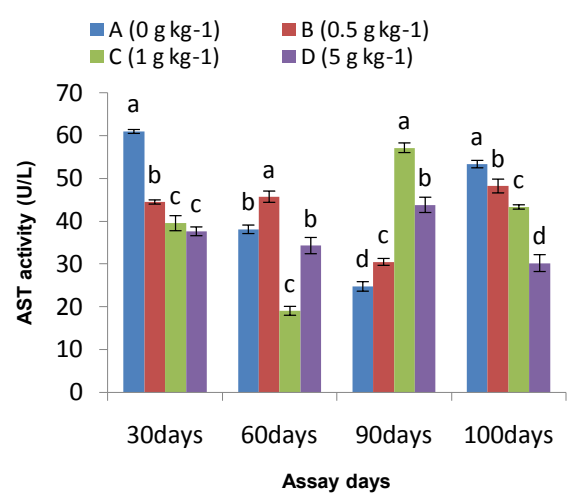

Figure 2: Effect of Microcystis on AST activity (U/L) of Labeo rohita on different assay days during the experimental period. Bars bearing common superscripts are not significant at $5 \%$ level in comparison to each other $(n=6)$. 


$$
\square(0 \mathrm{~g} \mathrm{~kg}-1) \quad \square \mathrm{B}(0.5 \mathrm{~g} \mathrm{~kg}-1)
$$$$
\text { - } \mathrm{C}(1 \mathrm{~g} \mathrm{~kg}-1) \quad \mathrm{D}(5 \mathrm{~g} \mathrm{~kg}-1)
$$

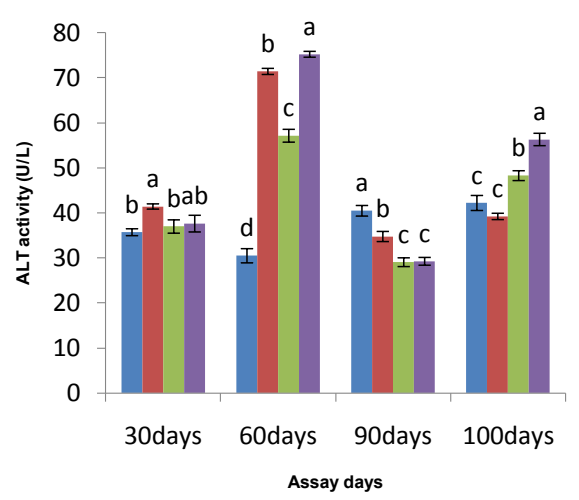

Figure 3: Effect of Microcystis on ALT activity (U/L) of Labeo rohita on different assay days during the experimental period. Bars bearing common superscripts are not significant at $5 \%$ level in comparison to each other $(n=6)$.
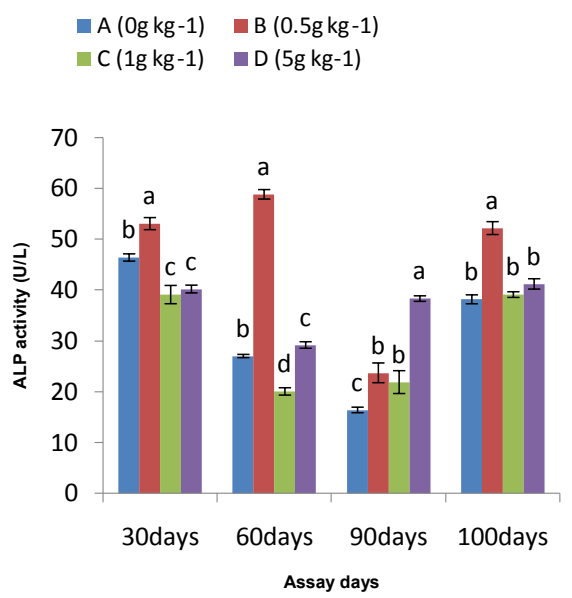

Figure 4: Effect of Microcystis on ALP activity (U/L) of Labeo rohita on different assay days during the experimental period. Bars bearing common superscripts are not significant at $5 \%$ level in comparison to each other $(n=6)$.

(Figure 3). A significant ( $\mathrm{p} \leq 0.05$ ) difference in ALP activity was found in all pre challenge treatment groups as compared to control in each assayed period as shown in Figure 4. But there was insignificant ( $p>0.05)$ difference of ALP level was found on day 10 bacterial post challenge (except B) as compared to control.

\section{Disease resistance}

After challenging the fish with A. hydrophila the mortality was recorded up to 10 th day. There was no mortality of fish up to $18 \mathrm{~h}$ post infection. The maximum survival was shown in group of fish fed $0.5 \mathrm{~g}$ $\mathrm{kg}^{-1}$ followed by $1.0 \mathrm{~g} \mathrm{~kg}^{-1}$.

\section{Discussion}

Microcystis besides producing toxins like Microcystin LR [26] it was found that it has potential use in the control of fish and shellfish diseases and also as immunostimulant $[13,15]$. Haematological and biochemical parameters have been acknowledged as valuable tools for monitoring fish health. So it is important to monitor the health status of fish after administration of Microcystis as feed additive in basic diet of fish.
Results of the haematological parameters of rohu fingerlings in this study showed that there were significant differences $(\mathrm{p} \leq 0.05)$ among different dietary groups. It has been shown that variables such as age, sex, dietary state and stress alter blood values $[27,28]$. In present study the total leucocyte count significantly $(\mathrm{p} \leq 0.05)$ increased in Microcystis fed group. This result is supported by another study [18], which found that there was an increase in the WBC count when L. rohita fingerlings were fed with Mango kernel. The increase in total leucocyte, neutrophils, lymphocytes and monocytes following feeding of algal and herbal diets supports the notion of antimicrobial properties of the algae $[14,29]$ and traditional herbal medicine $[17,30]$. The white blood cells of rohu are known to increase following immunostimulation [31,32] and feeding with algal diets for 90 days [5]. The result of present investigation shows that the total erythrocyte counts increased in group of fish fed with $1 \mathrm{~g} \mathrm{~kg}^{-1}$ Microcystis on day 90 and on day 10 after postchallenge cab be correlated with the observation in Nile tilapia, O. niloticus that showed decreased RBC number after bacterial inoculation [33]. No significant difference of total erythrocyte count among the groups. The erythrocyte count increased with the administration of Microcystis, which might indicate an immunostimulant effect. The findings conform to those by Duncan and Klesius [34], who reported that the number of erythrocytes was significantly $(\mathrm{p} \leq 0.05)$ greater in channel catfish fed with a diet containing $\beta$-glucan.

Glucose is one of the most important sources of energy for the animals. It has been reported as an indicator of stress caused by physical factors [35]. Blood glucose level in all the group of fish treated with $M$. aeruginosa supplemented diet showed no significant variation with the treatment groups on day 90 and after post challenge on day 10 (except group $\mathrm{B}$ and D). It shows that the fish were not under stress when fed with optimum level of Microcystis supplemented diets. Similar types of observation with different types of dietary supplementation were observed [36].

The present study was targeted to find out its impact on the fish by evaluating the major stress enzyme to liver taking a model fish rohu which contributes about more than $80 \%$ to the freshwater aquaculture production in India. The ALT and AST are indicates for the diagnosis of liver function [37] and damage [38]. Decreased AST and ALT activity in serum showed that oxaloacetate and glutamate are not available to Kreb cycle through this root of transmission [39]. Microcystins has been reported to impact the liver of fish [40,41]. ALT activity in the liver of fish fed the high algae meal diet was lower than that of the fish fed the control diet in the present study. Rabergh et al. [40] and Navratil et al. [42] reported that ALT and AST activities in blood plasma increased after common carp (Cyprinus carpio L.) received intraperitoneal injections of Microcystin-LR. However in our present study, dietary Microcystis did not increased the liver enzymes e.g. AST and ALT which might attributed either absence or less availability of Microcystin-LR. Increased activity of ALP was marked in group of fishes fed with Microcystis over the days and a significantly ( $\mathrm{p} \leq 0.05)$ higher ALP activity was observed in group of fish fed with $0.5 \mathrm{gkg}^{-1}$ dose for 60 days. Increased phosphatase activity indicates higher breakdown of energy reserved which are utilized for growth and survival of fishes. All these results indicate that Microcystis increases the resistance of $L$. rohita so that it can withstand the adverse conditions of a challenge. However, appropriate field trials remain necessary before using Microcystis as a feed additive in aquaculture farm.

\section{Acknowledgement}

The authors wish to thank the Director of the Central Institute of Freshwater 
Citation: Pradhan J, Das BK (2015) Effects of Supplementation Diet Containing Microcystis Aeruginosa on Haematological and Biochemical Changes in Labeo Rohita Infected with Aeromonas Hydrophila. J Aquac Res Development 6: 315. doi:10.4172/2155-9546.1000315

Aquaculture for encouragement and for providing facilities to carry out the work The work is carried out partly funding source of ICAR in the form of AP Cess grant and partly from the Department of Science and Technology in the form of Women Scientist-A Scheme.

\section{References}

1. Ibrahem MD, Fathi M, Mesalhy S, Abd El-Aty AM (2010) Effect of dietary supplementation of inulin and vitamin $\mathrm{C}$ on the growth, hematology, innate immunity, and resistance of Nile tilapia (Oreochromis niloticus). Fish Shellfish Immunol 29: 241-246.

2. Gatlin DM, Li P, Wang X, Burr GS, Castille F, et al. (2006) Potential application of prebiotics in aquaculture, 8th International symposium on aquaculture nutrition: 371-376.

3. Baulny MOD, Quentel C, Fournier V, Lamour F, Gourvello RL (1996) Effect of long term oral administration of $\beta$-glucan as an immunostimulant or an adjuvant on some nonspecific parameters of the immune response of turbot, Scophthalmus maximus. Dis Aquat Org 26: 139-147.

4. Goetz FW, Iliev DB, McCauley LAR, Liarte CQ, Tort LB, et al. (2004) Analysis of genes isolated from lipopolysaccharide-stimulated rainbow trout (Oncorhynchus mykiss) macrophages. Mol Immunol 41: 1199-1210.

5. Das BK, Pradhan J, Sahu S (2009) The effect of Euglena viridis on immune response of rohu, Labeo rohita (Ham.). Fish Shellfish Immunol 26: 871-876.

6. Rao YV, Das BK, Jyotirmayee P, Chakrabarti R (2006) Effect of Achyranthes aspera on the immunity and survival of Labeo rohita infected with Aeromonas hydrophila. Fish Shellfish Immunol 20: 263-273.

7. Sahu S, Das BK, Mishra BK, Pradhan J, Sarangi N (2007a) Effect of Allium sativum on the immunity and survival of Labeo rohita infected with Aeromonas hydrophila. J Appl Ichthyol 23: 80-86.

8. Sahu S, Das BK, Pradhan J, Mohapatra BC, Mishra BK, et al. (2007b) Effect of Mangifera indica as feed additive on immunity and resistance to Aeromonas hydrophila in Labeo rohita fingerlings. Fish Shellfish Immunol 23: 109-118.

9. Ardo L, Yin G, Xu P, Va'radi L, Szigeti G, et al. (2008) Chinese herbs (Astragalus membranaceus and Lonicera japonica) and boron enhance the non-specific immune response of Nile tilapia (Oreochromis niloticus) and resistance against Aeromonas hydrophila. Aquaculture 275: 26-33.

10. Shameel M (2008) Change of divisional nomenclature in the Shameelian Classicification of algae. Int J Phycol Phycochem 4: 225.

11. Ishida K, Matsuda H, Murakami M, Yamaguchi K (1997) Kawaguchipeptin B an antibacterial cyclic undecapeptide from the cyanobacterium Microcystis aeruginosa. J Nat Prod 60: 724

12. Zainuddin EN, Mundt S, Wegner U, Mentel R (2002) Cyanobacteria a potentia source of antiviral substances against influenza virus. Med Microbiol Immunol 191: 181-182.

13. Das BK, Pradhan J (2010) Antibacterial properties of selected freshwater microalgae against pathogenic bacteria. Indian J Fish 57: 61-66.

14. Pradhan J, Sahu S, Nilima P M, Mishra BK, Das BK (2011) Antibacteria properties of freshwater Microcystis aeruginosa (Kütz) to bacterial pathogen-a comparative study of bacterial bioassays. Ind J Animal Sci 81: 79-100.

15. Das BK, Pradhan J, Sahu S, Marhual NP, Mishra BK, et al. (2013) Microcystis aeruginosa (Kütz) incorporated diets increase immunity and survival of Indian major carp Labeo rohita (Ham.) against Aeromonas hydrophila Infection. Aquacult Res 44: 918-927.

16. Bahmani M, Kazemi R, Donskaya P (2001) A comparative study of some hematological features in young reared sturgeons (Acipense rpersicus and Huso huso). Fish Physiol Biochem 24: 135-140.

17. De Pedro N, Guijarro AE, Lopez-Patino MA, Marinez-Alvarez R, Delgado M (2005) Daily and seasonal variation in haematological and blood biochemical parameters in tench Tinca tinca. Aquacult Res 36: 1185-1196.

18. Roy SS (2002) Some toxicological aspects of chlorpyrifos to the intertidal fish Boleopthalmus dussumieri. University of Mumbai, India.

19. Misra CK, Das BK, Mukherjee SC, Pradhan J (2007) Effects of dietary vitamin C on immunity, growth and survival of Indian major carp Labeo rohita, fingerlings. Aquacult Nutr 13: 35-44.

20. Van Kampen EJ, Zijlstra WG (1961) Recommendations for haemoglobinometry in Human blood. Br JHaematol 13: 71.
21. Blaxhall PC, Daisley KW (1973) Routine haematological methods for use with fish blood. J Fish Biol 5: 771-781.

22. Wallnofer H, Schmidt E, Schmidt FW (eds) (1974) Synopsis der Leberkrankheiten. Georg Thieme Verlag. Stuttgart.

23. Rosalki RS (1993) Boerhringer Mannheim Gmblt analysis protocol. Clin Chem 39: 648

24. Schmidt FH (1974) Methodender, Harn- and Blutzucker Bestimmung II. In Boehringer Mannheim $\mathrm{GmbH}$ analysis protocol.

25. Duncan DB (1955) Multiple range and multiple F-tests. Biometrics 11: 1-42.

26. Oudra B, Loudiki M, Sbiyyaa B, Martins R, Vasconcelos V, et al. (2001) Isolation, characterization and quantification of microcystins (heptapeptides hepatotoxins) in Microcystis aeruginosa dominated bloom of Lalla Takerkoust lake-reservoir (Morocco). Toxicon 39: 1375-1381.

27. Barnhart RA (1969) Effects of certain variables on haematological characteristics of rainbow trout, Salmo gairdneri (Richardon). Trans Am Fish Soc 98: 411-418.

28. McCarthy DH, Stevensom JP, Roberts MS (1973) Some blood parameters of the rainbow trout (Salmo gairdneri Richardson). I. The kamloops variety. J Fish Biol 5: 1-8.

29. Das BK, Pradhan J, Pattnaik P, Samantaray BR, Samal SK (2005) Production of antibacterials from the freshwater alga Euglena viridis (Ehren). World $J$ Microbiol Biotechnol 21: 45-50.

30. Parry RM, Chandan RC, Shahani KM (1965) A rapid and sensitive assay of muramidase. Proc Soc Exp Biol (NY) 119: 384-386.

31. Misra CK, Das BK, Mukherjee SC, Pattnaik P (2006a) Effect of long term administration of dietary $\beta$-glucan on immunity, growth and survival of $L a b e o$ rohita fingerlings. Aquaculture 255: 82-94

32. Misra CK, Das BK, Mukherjee SC, Pattnaik P (2006b) Effect of multiple injections of $\beta$-glucan on non-specific immune response and disease resistance in Labeo rohita fingerlings. Fish Shellfish Immunol 20: 305-319.

33. Ranzani-Paiva MJT, Ishikawa CM, Eiras AC, Silveira VR (2004) Effects of an experimental challenge with Mycobacterium marinum on the blood parameters of Nile Tilapia, Oreochromis niloticus (Linnaeus, 1757). Brazilian Arch Biol Technol 47: 945-953.

34. Duncan PL, Klesius PH (1996) Dietary immunostimulants enhance nonspecific immune responses in channel catfish but not resistance to Edwardsiella ictaluri. J Aquat Anim Health 8: 241-248.

35. Manush SM, Pal AK, Das T, Mukherjee SC (2005) Dietary high protein \& vitamin C mitigate stress due to chelate claw ablation in Macrobrachium rosenbergi males. Comp Biochem Physiol- Part A 142: 10-18.

36. Das R, Raman RP, Saha1 H, Singh R (2013) Effect of Ocimum sanctum Linn (Tulsi) extract on the immunity and survival of Labeo rohita (Hamilton) infected with Aeromonas hydrophila. Aquacult Res 1: 1-11

37. Ozaki H (1978) Diagnosis of fish health by blood analysis.

38. Oda T (1990) The biology of liver

39. Shakoori AR, Mughal AL, Iqbal MJ (1999) Effects of sublethal dose of fenvalarate (a synthetic pyrethroid) administered for continuously for four weeks on the blood, liver and muscles of a fresh water $\phi$ sh, Ctenopharyngodon idella. Bull Environ Contam Toxicol 57: 487-494.

40. Rabergh CMI, Bylund G, Eriksson JE (1991) Histopathological effects of microcystin-LR, a cyclic peptide toxin from the cyanobacterium (blue-green alga) Microcystis aeruginosa, on common carp (Cyprinus aeruginosa L.). Aquat Toxicol 20: 131-145.

41. Rodger HD, Turnbull D, Edwards C, Codd GA (1994) Cyanobacterial (bluegreen algal) bloom associated pathology in brown trout (Salmo trutta L.) in Loch Leven, Scotland. J Fish Dis 17: 177-181.

42. Navratil S, Palikova M, Vajcova V (1998) The effect of pure microcystin LR and biomass of blue-green algae on blood indices of carp (Cyprinus carpio L.). Acta Vet (Brno) 67: 273-279. 